\title{
NOSOCOMIAL OUTBREAKS DUE TO PSEUDOMONAS AERUGINOSA AND ACINETOBACTER BAUMANNII IN A NEONATAL INTENSIVE CARE UNIT (NICU) OF THE UBERLÂNDIA FEDERAL UNIVERSITY HOSPITAL
}

\section{Denise Von Dolinger de Brito ${ }^{1 *}$; Elias Jose Oliveira ${ }^{1}$; Ana Lúcia da Costa Darini²; Vânia Olivetti Sttephen Abdallah ${ }^{1}$; Paulo Pinto Gontijo-Filho ${ }^{1}$}

\begin{abstract}
${ }^{1}$ Instituto de Ciências Biomédicas, Universidade Federal de Uberlândia, Uberlândia, MG, Brasil. ²Faculdade de Ciências
\end{abstract} Farmacêuticas, Universidade de São Paulo, Ribeirão Preto, SP, Brasil.

This paper corresponds to an "extended abstract" selected for oral presentation in the $22^{\text {nd }}$ Brazilian Congress of Microbiology, held in Florianópolis, SC, Brazil, in November 17-20, 2003

\begin{abstract}
The study documents the occurrence of two subsequent outbreaks in the NICU of HC-UFU, caused by epidemic strains of multiresistant Pseudomonas aeruginosa and Acinetobacter baumannii, that occurred between March/01 and September and between October/01 and March/02, respectively. The $P$. aeruginosa outbreak included seven neonates with conjunctivitis and three with bacteremia. A case-control study was conducted for the A. baumannii outbreak, with 11 and 22 neonates, respectively. The isolates of $A$. baumannii were resistant to gentamacin and ciprofloxacin. P. aeruginosa isolates were resistant to ampicillin/sulbactam gentamicin and ciprofloxacin. The hands of healthcare workers and environmental cultures were negative. The outbreak of $P$. aeruginosa resulted in the increase of use of imipenem, which could have favoured the emergence of a $A$. baumannii epidemic strain, despite of its susceptibility to this antibiotic. The risk factors for $A$. baumannii infection were: weight $<1500 \mathrm{~g}$, age $<7$ days, hospitalization $>7$ days and use of carbapenems. Containment of the two outbreaks was achieved by introduction of strict hygiene measures and careful nursing care of the infected infants. The reservatory and the route of transmission were not found.
\end{abstract}

Key words: outbreak, neonate, Acinetobacter baumannii, Pseudomonas aeruginosa.

\section{INTRODUCTION}

Pseudomonas aeruginosa and Acinetobacter baumannii are the most prevalent nonfermentative bacterial species isolated from clinical specimens of hospitalized patients $(1,5)$. This study documents the occurrence of two subsequent outbreaks in NICU, one caused by Pseudomonas aeruginosa and the other by $A$. baumannii. The outbreaks occurred from March/01 to September/ 01 and from October/01 to March/02, respectively.

\section{PATIENTS AND METHODS}

The $P$. aeruginosa outbreak affected ten babies. Three of them had positive blood culture and seven had conjunctivitis.
A case-control study was performed during the $A$. baumannii outbreak. The epidemic strains were $A$. baumannii resistant to gentamicin and ciprofloxacin, and $P$. aeruginosa resistant to ampicillin/sulbactam, gentamicin and ciprofloxacin. Once the outbreaks were detected, surveillance cultures were taken in three opportunities from the pharynx and rectum of all infants in the NICU. The hands of most healthcare workers and environmental samples were tested. The susceptibility to antibiotics was tested in Mueller-Hinton agar using the disk diffusion method according to NCCLS guidelines (2). All $A$. baumannii isolates were screened for resistance to ceftazidime and cefpime by the Minimum Inhibitory Concentrations (MICs) (3). 


\section{RESULTS AND DISCUSSION}

The outbreaks caused by $P$. aeruginosa and A. baumannii isolates, affecting ten and eleven infants, respectively, are observed in Fig. 1. P. aeruginosa infection was found in seven neonates with conjunctivitis and three with septicemia. Patients affected by the outbreak caused by $A$. baumannii strains presented clinical signs of sepsis. Cultures from the hands of health care professionals, environment, pharyngeal and rectal samples from neonates of NICU were negative for both organisms. The epidemic strains were susceptible to imipenem only. Risk factors included low birth weight $(\leq 1500 \mathrm{~g})$, age $\leq 7$ days, hospitalization $\geq 7$ days, and the use of carbapenem (4). All $P$. aeruginos $a$ and $A$. baumnannii isolates showed the same pattern of multiple resistance and susceptibility to imipenem. The $\mathrm{MIC}_{50}$ and $\mathrm{MIC}_{90}$ for ceftazidime and cefpime for $A$. baumannii were $1 \mu \mathrm{g} / \mathrm{mL}$ and $8 \mu \mathrm{g} / \mathrm{mL}$, respectively. From March/ 01 to September/01, an increase of use of imipenem due to the occurrence of $P$. aeruginosa outbreak was observed in the unit. This fact could have favoured the emergence of $A$. baumannii epidemic strain in spite of its susceptibility to this antibiotic.



Acinetobacter baumannii $\square$ Pseudomonas aeruginosa

Figure 1. Distribution of Pseudomonas aeruginosa and Acinetobacter baumannii infected patients in a Neonatal Intensive Care Unit. Uberlândia Federal University. January, 2001, to May, 2002.

Table 1. Risk factors for aquisition of Acinetobacter baumannii infection.

\begin{tabular}{lcrrrl}
\hline \multicolumn{1}{c}{ Risk factor } & \multicolumn{1}{c}{ Case $\mathbf{N}=\mathbf{1 1}$} & \multicolumn{1}{c}{ Controls N=22 } & p \\
\hline Weight & $\mathrm{N}$ & \multicolumn{1}{c}{$\%$} & $\mathrm{~N}$ & \multicolumn{1}{c}{$\%$} & \\
\hline$>1500 \mathrm{~g}$ & 4 & 36.4 & 17 & 77.3 & \\
$\quad \leq 1500 \mathrm{~g}$ & 7 & 69.6 & 5 & 22.7 & $0.05^{*}$ \\
Age & & & & & \\
$\quad>7$ dias & 7 & 63.6 & 21 & 95.4 & $0.03^{*}$ \\
$\quad \leq 7$ dias & 4 & 36.4 & 1 & 4.6 & \\
Hospitalization & 10 & 90.9 & 6 & 27.3 & $0.002^{*}$ \\
$\quad(\geq 7$ days) & & & & & \\
Incubator & 11 & 100.0 & 20 & 20.9 & 0.54 \\
Antibiotic & 11 & 100.0 & 12 & 54.5 & 0.4 \\
Carbapenem & 11 & 100.0 & 0 & & $0.0000001^{*}$ \\
\hline
\end{tabular}

\section{CONCLUSION}

Containment of the two outbreaks was achieved by employment of strict hygiene measures and careful nursing care of the infected infants. The reservatory and route of transmission were not found.

\section{RESUMO}

\section{Surto hospitalar por Pseudomonas aeruginosa e Acinetobacter baumannii em uma unidade de terapia intensiva neonatal (UTIN) do Hospital de Clínicas da Universidade Federal de Uberlândia (HC-UFU)}

O objetivo foi relatar a ocorrência de dois surtos subseqüentes na UTIN do HC-UFU, por amostras epidêmicas de $P$. aeruginosa e A. baumannii multirresistentes nos períodos de Mar - Set/01 e Out - Mar/02, respectivamente. O surto por P. aeruginosa incluiu sete neonatos com conjuntivite e três com bacteremia e um estudo caso-controle foi realizado no surto por $A$. baumannii com $11 \mathrm{e}$ 22 neonatos respectivamente. Os isolados de $A$. baumannii foram resistentes a gentamicina e ciprofloxacina e os de P. aeruginosa a ampicilina/sulbactam além de gentamicina e ciprofloxacina. As culturas ambientais e das mãos dos profissionais de saúde foram negativas. O surto por $P$. aeruginosa resultou no aumento do uso de imipenem o que pode ter favorecido a emergência do surto por A. baumannii que embora suscetível a este $\beta$-lactâmico apresentou uma multiresistência importante. A análise univariada relacionou os fatores de risco predisponentes para infecção por A. baumannii: peso $<1500 \mathrm{~g}$, idade $<7$ dias, hospitalização $>7$ dias e uso de carbapenema. O término dos surtos foi alcançado através medidas de controle de infecção e isolamento de coorte dos neonatos infectados, não sendo possível definir o reservatório e a via de transmissão.

Palavras-chave: surto, neonato, Acinetobacter baumannii, Pseudomonas aeruginosa.

\section{REFERENCES}

1. Karlowsky, J.A.; Draghi, D.C.; Jones, M.E. et al. Surveillance for antimicrobial susceptibility among clinical isolates of Pseudomonas aeruginosa and Acinetobacter baumannii from hospitalized patients in the United States, 1998 to 2001. Antim. Ag. Chemother, 47:1681$1688,2003$.

2. National Committee for Clinical Laboratory Standards: Performance standards for antimicrobial disk susceptibility. Approved standard M2-A5. NCCLS, Villanova, PA, 1997a.

3. National Committee for Clinical Laboratory Standards: Methods for dilution antimicrobial susceptibility tests for bacteria that grow aerobically. Approved standard M7-A4. NCCLS, Villanova, PA, $1997 \mathrm{~b}$.

4. Pillay, T.; Pillay, D.G.; Adhikari, M. et al. An outbreak of neonatal infection with Acinetobacter linked to contaminated suction catheters. J. Hosp. Infect., 43:299-304, 1999.

5. Shah, S.S.; Gallagher, P.G. Complications of conjunctivitis caused by Pseudomonas aeruginosa in a newborn intensive care unit. Pediatr. Infect. Dis. J., 17:97-102, 1998. 